\title{
ENERGY USE AND RELATED RISK MANAGEMENT PROBLEMS IN CEE COUNTRIES
}

\author{
R. Ney \\ Silesian High School for Management \\ U1. Krasinskiego 2, 40952, Kotowice, POLAND \\ J. Michna \\ International Center for Energy and Environmental Policy, \\ 3 Wilhelmstrasse D-69181 Leimen, GERMANY \\ J. Ekmanis, N. Zeltins, V. Zebergs \\ Institute of Physical Energetics, \\ 21 Aizkraukles Str., Riga, LV-1006, LATVIA
}

\begin{abstract}
Nowadays, the efficiency of energy use in the Central and East-European (CEE) countries is insufficient, being much lower than in the "Old Europe". The problem becomes increasingly pressing due to non-stop increasing prices of energy carriers (especially of crude oil). The authors trace the development of research activities in this sphere, classifying the revealed changes in parameters of energy consumption processes in particular time intervals into deterministic, probabilistic, and fuzzy. The paper presents a thorough analysis of decision-making in the energy management at its different levels - normative, strategic, and operative. Particular attention is given to the management under uncertainty conditions - i.e. to the risk management. The most wanted research directions in this area proposed by the energy and environment policy (EEP) Center specially created for CEE countries concern management under risk connected with innovations, international activities, loss of reputation, etc.. The authors consider in detail the risk management with insufficient knowledge (non-knowledge) and under chaos. Much consideration is given to the scenario management and the game theory principles as related to the sphere of energy use.
\end{abstract}

\section{INTRODUCTION}

One of the most pressing problems whose solution needs a holistic approach is the low energy efficiency still existing in CEE countries (EU members since 2004 included).

The "Old" EU countries have, to a large degree, solved the problem of excessive energy consumption by developing modern technologies and improving the structure of primary energy carriers. Meanwhile, in the CEE countries high energy consumption reduces the economy competitiveness; this problem is urgent owing to progressively increasing prices of energy carriers, especially as regards crude oil prices. Therefore it is necessary that the energy efficiency be improved both in energy production and consumption spheres.

In many developed countries lower energy consumption was achieved in spite of rapid economic progress: while in the 70-ties of the past century the 
increase in energy consumption in the WE countries was $11 \%$, their national income increased in this period by $33 \%$. The same tendency, though to a smaller scale, could be noticed in succeeding years.

Already in the 60-ties of the last century, research works were carried out into the uncertainties associated with the management of energy production and supply under the conditions of CEE countries. In practice, just at that time the indices of energy consumption often suffered considerable dispersions. The relevant statistics was not accurate enough, and the research results were therefore applied to operative diagnosis of energy consumption in particular time intervals. More detailed research resulted in classification of the parameters and couplings describing energy consumption problems. These are as follows.

1) Deterministic:

- stable, resulting from:

- organisation of technological processes,

- planned interruptions in production,

- assumed model of energy consumption model,

- unstable, resulting from:

- transient problems,

- partial changes in operative processes,

- chaotic situations arisen.

2) Probabilistic:

- fluctuations of technological parameters,

- fluctuations of energy carriers' parameters,

- changes in the behaviour of people,

- natural implications in the discussed processes.

3) Fuzzy:

- some of the parameters and couplings of a discussed process,

- the chosen model of energy consumption,

- problems resulting from non-knowledge.

At analysing the energy consumption in technological processes of an enterprise, the authors suggest three logical management levels - normative (through regulations), strategic, and operative, where parameters and couplings have different aggregation (Fig. 1).

Modelling of energy consumption and saving processes needs a penetrating and complex analysis, which calls for new approaches.

First models developed in this direction took into account only deterministic parameters. Later on, they have progressively been extended, including also probabilistic and fuzzy parameters - i.e. parameters that in principle have uncertainties and scatter in values.

Under the uncertainty conditions the sensitivity analysis ${ }^{1}$ has received wide acceptance. Its aim is to achieve that the number of parameters and couplings be reduced to the most essential for the discussed process. A thorough recursive sensitive model structure is shown in Fig. 2.

\footnotetext{
${ }^{1}$ A method of analysis which introduces variations into the explanatory variables in a model to examine what effect they have upon the explained variable.

Energy Dictionary of World Energy Council.
} 


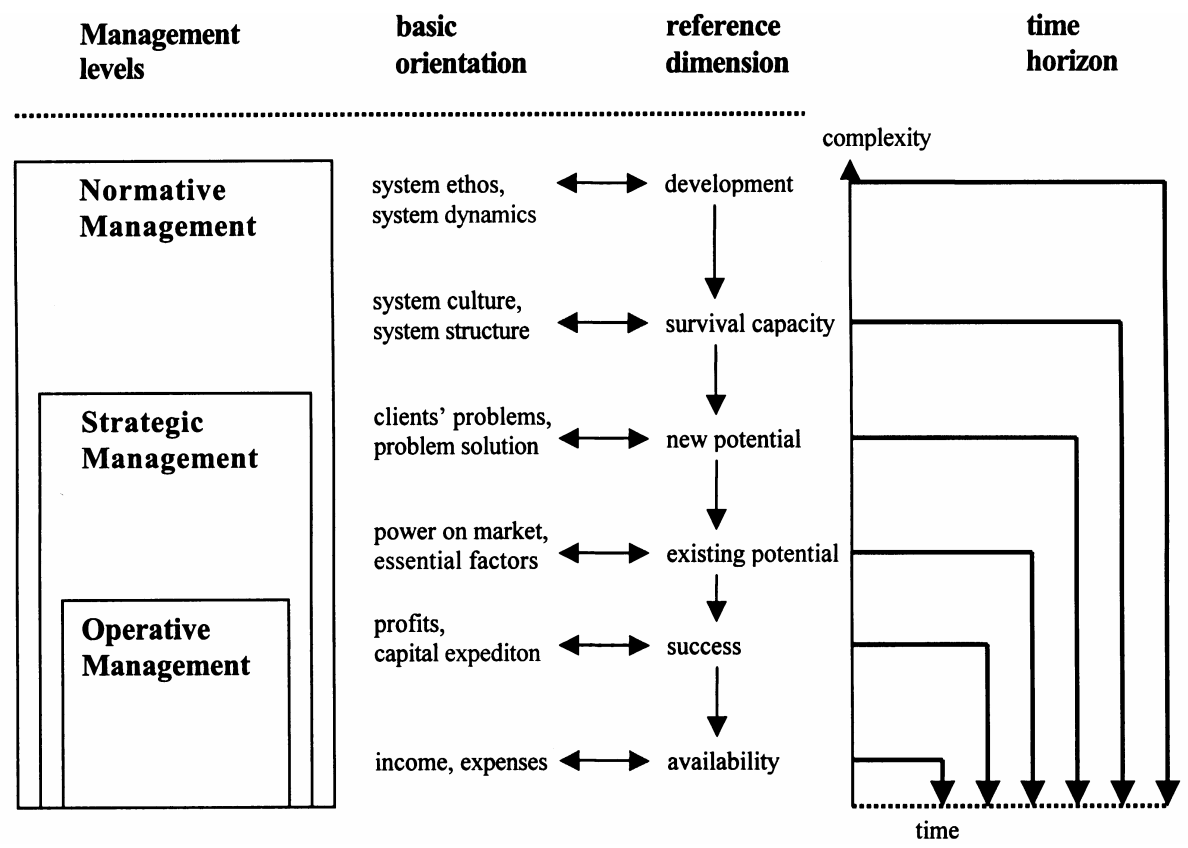

Fig. 1. Logical levels of enterprise management.

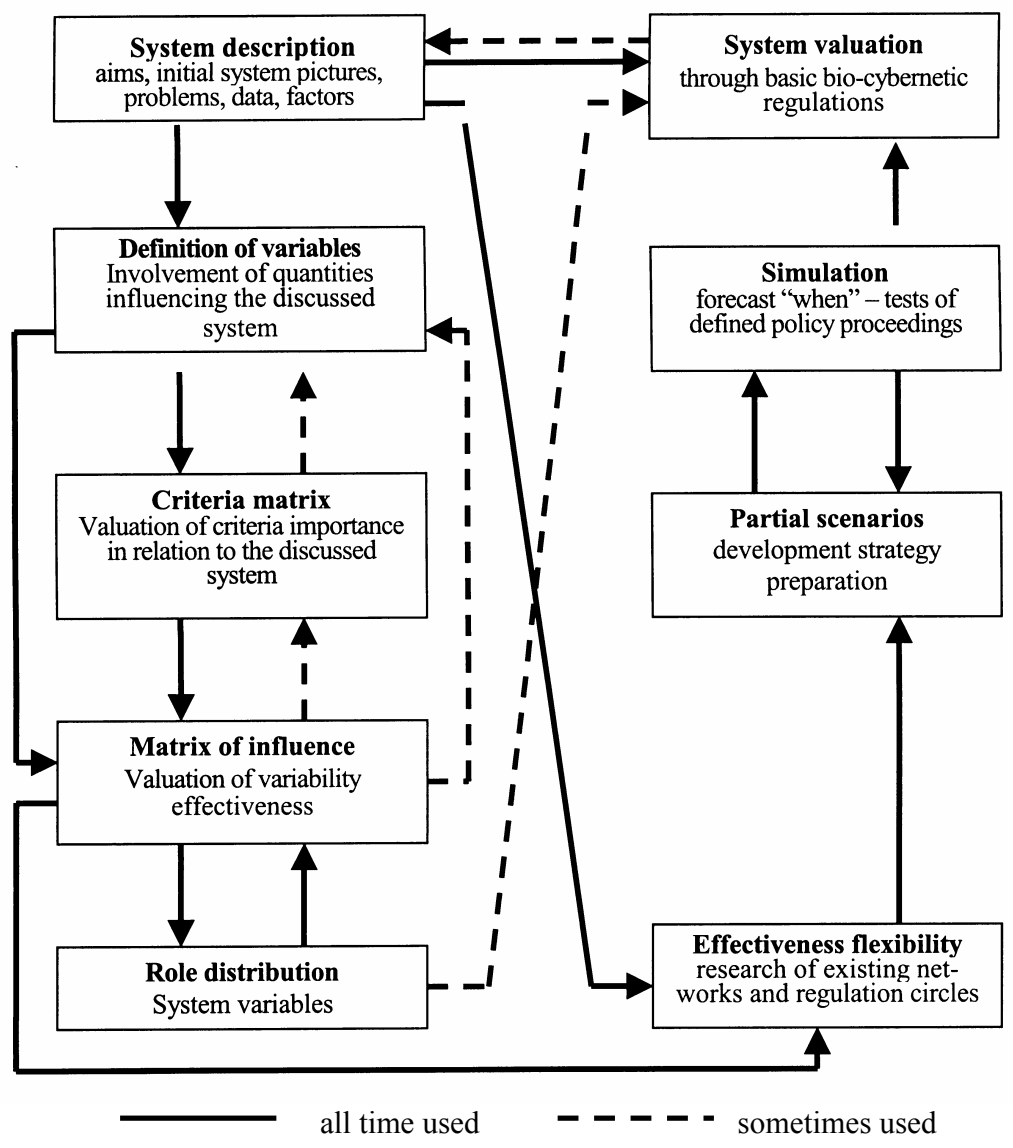

Fig. 2. Recursive sensitive model structure. 


\section{RESEARCH INTO RISK MANAGEMENT \\ IN CEE COUNTRIES}

Under the uncertainty conditions the so-called risk management has received wide recognition. Since in practice it is impossible to fully avoid risk, the main purpose of such management is to help an enterprise (or another institution) find answer to the question: is it reasonable, in every particular case, to manage under the existing level of risk?

The links and structure of risk management in the enterprising practice under the CEE conditions can be illustrated by Fig. 3 .

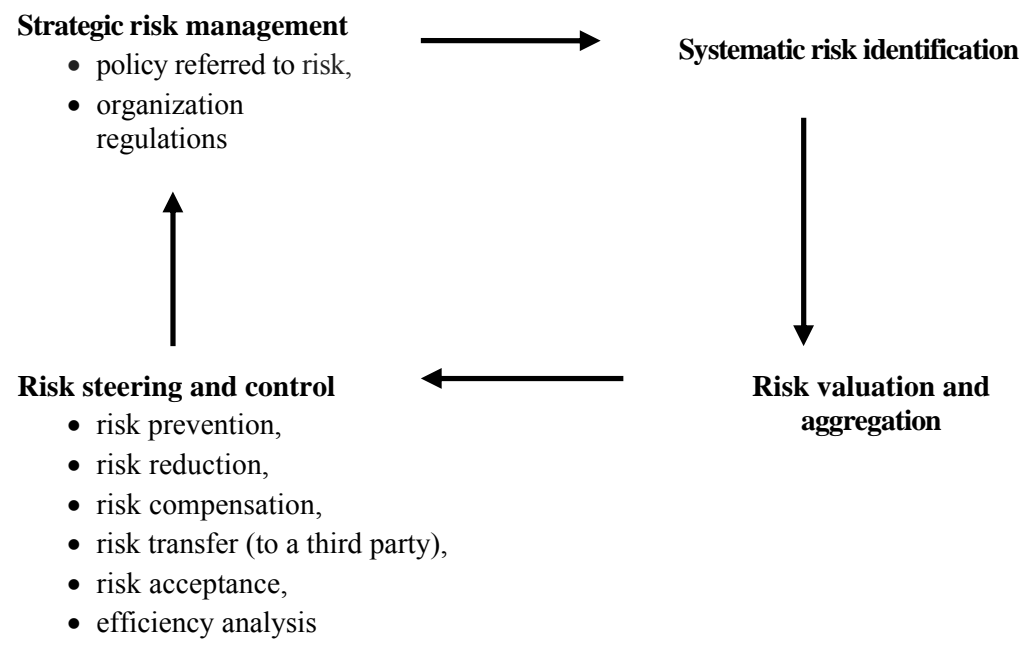

Fig. 3. Risk management in the enterprising practice.

In 2005, at the Energy and Environment Policy Centre (EEPC) of CEE countries the start was done for research into methods for organisation and realisation of risk management at enterprises and other institutions, especially in the scope of energy and environment conservation policy. Its results would allow defining and forecasting the state of risk management in the economic policy pursued by the government of a particular country.

Based on the expert estimations made in all CEE countries, the following themes have been approved at the EEPC as the most important in the energy conservation sphere:

1) Risk management of innovations.

2) Management of international risk influencing energy conservation.

3) Management of reputation risk associated with energy conservation.

4) Management under chaos.

5) Management with insufficient knowledge (non-knowledge).

6) Scenario management and the game theory principles as related to the energy conservation sphere.

These themes are illustrated by Fig. 4 (considered below in more detail). 


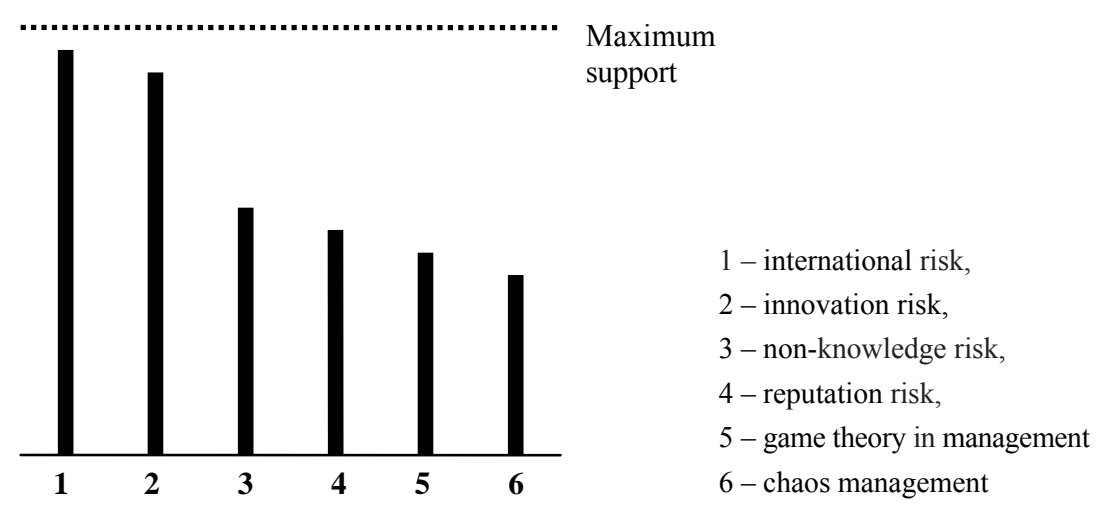

Fig. 4. Attractiveness of planned research into risk management in CEE countries.

\section{Risk management of innovations in the energy conservation sphere}

Today, the innovation management has gained wide recognition.

Of especial importance in this sphere of risk management is to develop the creative potential of employees and to help them acquire the knowledge needed for applying their ideas to practice. For this purpose complex-thinking principles should be employed, which could be helpful in establishing links between the authors of ideas and those promoting these ideas. Such thinking, when applied to energy saving innovations, implies taking into consideration probabilistic and/or fuzzy parameters as well as situations characterized with insufficient knowledge or with non-knowledge.

In a thorough search for innovations it is possible to distinguish four main types of activities:

- introduction of new technologies,

- structural renovation of energy using systems,

- technical and organizational improvements,

- replacement of the used energy carriers by more efficient.

In these activities the following aspects need consideration:

- potential of innovations in the sphere of energy use,

- realisation effect of a particular innovation,

- expenses needed for realisation the innovation,

- realisation time for the innovation,

- reliability of the innovation at work.

Based on the knowledge available in the discussed scope, it is necessary to perform the general assessment of uncertainties for every particular innovation and the risk evaluation of its effect.

Methods based on complex thinking principles in the risk management of innovations are to be used for analyzing:

- innovation effect sensitivity (using parameters and couplings describing a particular innovation),

- dynamics of changes,

- probability calculations,

- calculations of fuzzy parameters and relations.

Therefore, competent and elastic selection among existing methods is needed for determination of the potential of energy saving innovations. Very useful 
and efficient in this scope would be analysis of experience acquired by different countries with similar socially-economical development conditions. Currently, further research into the innovation risk is planned, with attraction of experts from all CEE countries.

\section{Risk management in the international context}

In the last years, the risk management problems, to an increasing degree, are arising also in the international activities related to the sphere of energy economy.

Particularly, this refers to the problems stemming from wide diversity of methods employed by the buying and selling organisations. We should take into account that the risk that could be ignored on a national scale sometimes becomes inadmissible in the international context. Indeed, there are international conventions which, being accepted by CEE countries, are obeyed to a higher degree than corresponding internal regulations.

Of paramount importance all over the world are stock-exchange fluctuations, which affect the prices of energy carriers. Therefore better forecasts of tendencies are needed so that appropriate measures for compensation of changes in energy carrier prices could be taken to secure the survival ability for enterprises - and for the state as a whole.

During realization of an international project, specific uncertainties and risk can arise - in particular, at implementation of a concrete innovation, owing to:

- differing regulations accepted in a concrete state,

- existing culture, organisation, technical measures and methods of management at a concrete enterprise,

- the client's wishes,

- requirements imposed on a concrete project.

Innovation management under potential risk in the projects with foreign participants becomes an involved problem for developing enterprises. The main difficulties are coming from the lack of needed information, in particular about the experience of other competitors. Therefore it is necessary to examine the methodical approaches to innovation management under risk accepted in other countries, especially in those with similar conditions (i.e. post-transition countries).

\section{Reputation in the risk management.}

By the reputation risk we understand the danger of losses that could be incurred by an enterprise (or another organization) resulting from its reputation.

As known, reputation is difficult to earn but is easy to lose. It is an essential factor for achieving success in concrete socially-economic activities, in particular, in managing an enterprise (organisation).

Today, reputation is treated as independent financial means that can be transferred to other capital carriers by the owner of a concrete enterprise. A positive reputation can be achieved through organisation and appropriate advertising of novel effects obtained by an enterprise, in particular through:

- well organised and realised original technically-organisational innovations,

- efficient specialisation of energy conservation solutions,

- complementary research into practical efficiency of every particular solution,

- creation of appropriate culture for energy conservation activities. 
Reputation risk is usually a result of certain events and not a casual risk. Therefore it can be lost - for a short time or forever. In big enterprises the loss of positive reputation is directly associated with the results of stock exchange activities; as concerns small enterprises, such a loss will be seen on regional markets - through a decrease in the demand for products or services of a concrete enterprise.

In the scope of energy conservation, loss of positive reputation is to be observed after events having a negative long-term influence on the confidence in the enterprise both from internal and external sides.

Currently, research works into the reputation risk are insufficient. In the future, it is planned to study the implications of reputation risk under the conditions of CEE countries (in the sphere of energy conservation included).

\section{Chaos Management}

The categories of uncertainties and risk are - to a progressive extent related to the phenomena defined as chaos. This notion is usually contrasted with the lack of ordering. As we remember from mythology, chaos was treated there as a furious shapeless mass. Nowadays, chaos is defined as an unpredictable system that underlies deterministic principles. From the mathematical point of view, chaos is not a shapeless mass but a definite complex mathematical structure.

It is recognised now that some deterministic systems are basically chaotic and unpredictable. However, chaos can be described by nonlinear equations characterizing the quality of a system.

One of the features of a chaotic system is its unlimited sensitivity to the boundary conditions required for solution of the equation set describing the system. In other words, a minor deviation from the boundary conditions can create fully new functions for describing the mentioned system. If earlier this was attributed to errors arising at measuring the parameters, now it is recognised that this feature (quality) is intrinsic in every system of the kind. In this situation we are speaking about "deterministic chaos" - the notion that has emerged recently, although in classical mechanics it has long been known (in fact, the theory of chaos is based on the Newtonian mechanics).

A considerable number of chaotic systems can be represented by the socalled singular attractors (describing the tendency of a dynamic system to reach a definite state), which allows the chaos theory to be connected with the discipline known as fractal geometry.

By "fractal" (a notion that was introduced in the year 1975 by Mandelbrot, a Polish scientist) we understand a fringed geometrical figure whose shape repeats in a smaller scale and which can be described by a fractal (not integer) dimension.

The fractal quality notion can be met in many disciplines, and recently also in risk management problems (interesting enough, in practice the most successful enterprises possess fractal qualities, which could be observed on all management levels).

Fractals and singular attractors allow for introduction of regulations according to which globally stable but locally variable structures can be built by self-organising systems. In simpler words, for efficient management of an enterprise it is important that such basic factors as future visions, value scales, organi- 
sational principles, etc., be known by employees, which should be able to choose among these factors.

Nowadays, existing experience along with opportunities provided by intensively progressing achievements of chaos theory open new ways for development in the scope of energy conservation.

\section{Management in situations without appropriate knowledge}

It is commonly noticed that just the main problems are poorly provided with needed information. Paradoxically enough, in the last time - that is, a time of progress in knowledge - permanent appearance of new forms and scopes of the socalled non-knowledge could be observed. Situations characterised with nonknowledge should be treated as creating additional sources of uncertainty and risk.

Unfortunately, it is impossible all the time to substitute the scientificallysupported knowledge for non-knowledge on a concrete problem, since there always are attendant problems (concerning materials, machines, equipment, qualified personnel, etc.) that should be solved for realisation of a concrete activity (e.g., an innovation). Even not always is it possible to evaluate intended or non-intended side effects of certain activities (e.g. risk management). Science so far is unable to assure full knowledge, and often we have to do with is only comparative scientific knowledge. In the decision-making processes we have constantly to reckon with certain limits (or "gaps") in our knowledge; for instance, competence limits of a scientific discipline, local limits for planned activities, etc. In our methods, it is advisable and even necessary to make allowances for both the knowledge and nonknowledge states.

At the present time, the following categories can be proposed for characterising insufficient or absent knowledge:

- uncertain knowledge,

- non-scientific knowledge,

- non-knowledge,

with sometimes only a fuzzy border between them (even in natural sciences). For acting in non-knowledge situations special logic should be worked out.

In many activities of the economy practice, such situations are increasing in number, since the financial allocations into the relevant research are insufficient. Meanwhile, non-knowledge poses tasks for science - e.g. personal limits of knowledge, its future horizons, improvement of common knowledge taking into account the most significant contexts (which is especially important for achieving definite socially-economic aims), etc.. It is therefore very useful to exercise standards for treating the notion of knowledge, not forgetting that they would allow only a fragmented view of a complex problem; in other words, it should be remembered that non-knowledge is also a factor among others in strategic thinking.

Concerning non-knowledge in the scope of energy conservation, the most urgent future activities need:

- normative directions for acting in the discussed scope (which means revision of existing principles);

- institutional support;

- complex scientific research into the risk management in non-knowledge situations. 


\section{Scenario management: the game theory principles}

Uncertainties typically met in practice of decision-making at a concrete enterprise create a need for complex research that would provide a thorough risk analysis for this enterprise. For this purpose the Scenario ${ }^{2}$ Management approach can be employed; with this notion another one is closely connected - the so-called scenario thinking based on the following methods of basic thinking:

- complex thinking,

- thinking open for the future,

- strategic thinking.

Such an approach allows for complex diagnosis of the current state of an enterprise and for estimation of its risk level and development potential. Of essential importance becomes the choice among the following scenarios:

- surrounding scenario (relating to external problems of a system),

- steering scenario (relating to internal problems of a system),

- "mixed" scenario (relating to mixed problems of a system).

In principle, all the above mentioned scenarios are based on the information gathered by their designers. Meanwhile, opponents are also thinking, as they try hard to win the competition. This explains the game theory's coming into play, whose principles could be used in scenario management, especially for estimation of chances and risk associated with a particular problem, and for preparation of a better solution than that of potential competitors. The game theory can successfully be applied to analysis of the problems that without invoking this theory cannot even be noticed. Besides, the game theory allows for modelling the conflicts and cooperation, which are speeding-up factors for creation of all risk categories.

What is important for risk management - the game theory takes into account the dynamicity of the processes in economy systems. Therefore, this theory can help an enterprise to adapt itself for potential changes. In practice, the game theory is often more helpful than exact theories in making better decisions.

As concerns problems connected with the choice of innovations and methods for their realisation in the area of energy conservation, the game theory can indicate the ways of how to win competition.

\section{CONCLUSIONS}

Since the issue of energy conservation is of vital importance for CEE countries, it is necessary to do in this area the following:

1. To work out the methods for treatment of the above described risk categories.

2. To study the most efficient new experience in the discussed scope which could be adapted for the conditions of CEE countries.

3. To develop efficient methods for risk management under the conditions of CEE countries.

It is also advisable to organise permanent exchange of experience acquired in CEE countries in the scope of energy conservation, especially in relation to specific problems characterized by probabilistic and fuzzy parameters.

\footnotetext{
2 Scenario is coherent and plausible combination of hypotheses, systematically compiled about the exogenous variables of a forecast.

Energy Dictionary of World Energy Council
} 
It is necessary to organise purposeful national programmes on the energy efficiency, with the aim to achieve not only a "typical" energy saving but a distinctive increase in the efficiency of consumed energy - that is, figuratively speaking, to obtain more product from smaller energy units (for instance, following such a principle allowed the Polish economy to develop without or with minimum increase in the energy consumption).

To achieve better results in the energy use, simple stimulation methods employed so far are insufficient. Therefore an urgent need exists to find new effective stimulation methods that would allow complex management ensuring progress in this sphere.

\section{REFERENCES}

1. Kapala, J., Michna, J., Ekmanis J., \& Zeltinsh, N. (1998). Research-based ecological concept of energy management for the Baltic states in the transition period. Latv. J. Phys. Tech. Sci., 5, 3-13.

2. Ekmanis, J., \& Zeltiņš N. (2000). Five-year cooperation of the Polish and Latvian Academies of Science in the field of energy \& ecology. Latv. J. Phys. Tech. Sci., 1, 3-8.

3. Ekmanis, Yu., Frormann, D., Kapala, J. Mihna, J., \& Zeltinsh, N. (2001). Analysis of the energy and environment in the CEE countries: from preparatory phase to posttransition. Latv. J. Phys. Tech. Sci., 5, 3-13.

4. Frormann, D., Michna, J., Stania, A., Ekmanis, J., Zeltins, N., \& Zebergs, V. (2006). Risk management problems of energy and environmental policy in Central and Eastern European countries. Latv. J. Phys. Tech. Sci., 3, 66-73.

5. Bieta, V., Kirchhoff, J., Milde, H., \& Siebe, W. (2004). Szenarienplanung im Risikomanagement. Weinheim: Wiley.

6. Black, J., Lodge, M., \& Thatcher, M. (2005). Regulatory Innovation. EE Cheltenham (UK), Northhampton (USA).

7. Boschen, S., Schneider, M., \& Lerf, A. (2004). Handeln trotz Nichtwissen. Campus, Frankfurt/New York.

8. Bruhn, M., \& Hadżich, K. (2006). Produkt- und Servicemanagement Vahlen. Monachium.

9. Barney, L., Wayne, \& C., Kennedy, W. J. (2001). Guide to Energy Management. Fairmont Press.

10. Convery, F. (2000). A guide to policies for energy conservation. EE Cheltenham (UK), Northhampton (USA)

11. Dietl, G., \& Lobinger, W. (2006). Risikomanagement fur Geschaftsprozesse. Hanser Monachium, Wiedeń.

12. Finkę, R. (2005). Grundlagen des Risikomanagement. Weinheim: Wiley.

13. Gleisner, W., \& Romeike, F. (2005). Risikomanagement. Haufe: Berlin; Monachium: Zurich.

14. Kaiser, T. (2007). Wettbewerbsvorteil Risikomanagement. Berlin: ESV.

15. Mandelbrot, B. (2005). The (mis)behaviour of markets. New York: Perseus group.

16. Mulder, P. (2005). The economics technology diffusion and energy efficiency. EE Cheltenham (UK), Northampton (USA).

17. Meier, P., \& Munsinghe, M. (2005). Sustainable energy in developing countries. EE Cheltenham (UK), Northampton (USA).

18. Merbecks, A., Stegemann, A., \& Frommeyer, J. (2004). Intelligentes Risikomanagement Ueberreuter. Frankfurt: Wiedeń.

19. Michna, J. (2007). Zarzadzanie Ryzykiem Produkcji. SWSZ: Katowice.

20. Michna, J. (2006). Small and Medium Enterprises' Development in CEE. London: IJ Entrepreneurship and Innovation Management. 
21. Michna, J. (2003). Zarzqdzanie Produkcja. SWSZ: Katowice.

22. Michna, J. (1987). Polityka racjonalizacji użytkowania paliw $i$ energii. UNDP/UNIDO Project: Vienna.

23. Michna, J. (1976). Metoda prognozowania wykresów statystycznych różnych postacie energii w zakładzie przemyst. Zeszyty naukowe Poi. Śląskiej- Energetyka.

24. Michna, J. (1969). Analiza zmienności wytwarzania $i$ zużywania paliw gazowych $w$ hutnictwie.Warszawa: GPiE.

25. Piel, K. (2005). Ekonomie des Nichtwissens. Campus, Frankfurt, New York.

26. Pinnels, J., \& Pinnels, E. (2007). Risikomanagement in Projekten. Gabler: Wiesbaden.

27. Praag, C.M. (2005). Successful Entreneurship. EE Cheltenham (UK), Northhampton (USA).

28. Romeike, F. (2005). Modernes Risikomanagement. Wiley: Weinheim.

29. Shapira, P., \& Kuhlmann, S. (2003). Learning from science and technology policy evaluation. EE Cheltenham (UK), Northampton (USA).

30. Smith, L. (2007). Chaos. Oxford.

31. Sornette, D. (2003). Critical Phenomena in Natural Science. Berlin, New York: Springer.

32. Stoop, R., \& Steeb, W. (2006). Berechenbares Chaos. Basel, Boston, Berlin: Birhauser.

33. Strohmeier, G. (2007). Ganzheitliches Risikomanagement in Industrie. Wiesbaden.

34. Trautmann, S. (2007) Investitionen. Berlin, Heidelberg, New York: Springer.

35. Wólkę, T. (2007). Risikomanagement. Oldenbourg, Monachium: Wiedeń.

36. Wesseler, J., \& Weikard, H. (2004). Risk and Uncertainty in Environmental and Natural Resource Economics. EE Cheltenham (UK), Northampton (USA).

37. Wygoda, S. (2005). Risiko als Chance. Berlin: WVB.

38. Zhon, Li, \& Halang, W. (2006). Integration of Fuzzy Logic and Chaos Theory. Berlin, New York: Springer.

\title{
RISKA VADĪBAS PROBLĒMAS ENERĢIJAS POLITIKĀ CENTRĀLEIROPAS UN AUSTRUMEIROPAS VALSTĪS
}

\author{
R. Ney, J. Michna, J. Ekmanis, N. Zeltinšs, V. Zēbergs
}

Kopsavilkums

Patreiz Centrāleiropas un Austrumeiropas valstīs (CEAEV) energijijas izmantošanas efektivitāte ir nepietiekama, tā ir mazāka nekā "Vecā Eiropā". Problēmas risinājums kḷūst aizvien steidzamāks sakarā ar nepārtrauktu enerǵijas resursu cenu celšanos (sevišķi naftai). Tā kā Centrāleiropas un Austrumeiropas valstīs ir vēl nevienmērīga ekonomiskā attīstība, uzmanība jāvelta vadībai nenoteiktības apstāklos - t.i. riska vadībai.

Autori detalizēti pēta tādus riska vadības veidus kā inovāciju vadību, vadību saistītu ar starptautiskām aktivitātēm, ar uzṇēmumu reputācijas zaudēšanu utt. Sevišķa uzmanība veltīta riska vadībai nepietiekošu zināšanu vai to trūkumu apstākḷıs, kā arī vadībai haosa apstākḷos.

22.01.2008. 